九州大学学術情報リポジトリ

Kyushu University Institutional Repository

\title{
A Study of the Causal Factors for Farm Mechanization in Sri Lanka
}

Ul luw i shewa, Rohana

Seminar of Econometric Analysis in Agriculture, Faculty of Agriculture, Kyushu University

Tsuchiya, Keizo

Seminar of Econometric Analysis in Agriculture, Faculty of Agriculture, Kyushu University

https://doi.org/10.5109/23781

出版情報: 九州大学大学院農学研究院紀要. 28 (2/3)，pp.91-110, 1983-12. Kyushu University バージョン：

権利関係 : 


\title{
A Study of the Causal Factors for Farm Mechanization in Sri Lanka
}

\author{
Rohana Ulluwishewa and Keizo Tsuchiya \\ Seminar of Econometric Analysis in Agriculture, Faculty of \\ Agriculture, Kyushu University 46-07, Fukuoka 812 \\ (Received September 8, 1983)
}

\begin{abstract}
Farm power transition from man power and animal power to mechanical power has been in progress in the tillage operation on paddy fields in Sri Lanka. In contrast to small paddy farmers in Japan, Sri Lankan farmers whose family income is not adequately supported by non-farm jobs are financially incapable of keeping their own farm machines. Nevertheless, farm mechanization is in progress. Thousands of small farmers living below the poverty line use farm machines hired from the farm power owners. Farm power owners, by virtue of their monopoly over the farm power hire market successfully pass on the increased costs on machines to the hirers by raising the hire rates. At the first sight, it seems to be difficult to find rational grounds for Sri Lankan farmers' tendency towards mechanization. However, it has been observed in a number of micro-level socio-economic surveys that the scarcity of man power, animal power, time and water during the rather short ploughing period generates compelling grounds for farmers to substitute mechanical power for animal power. This study is intended to observe this contention at the national level. Multiple regression analysis based on country-wide cross-sectional data suggests that $51 \%$ of the spacial variation in the degree of mechanization is associated with the factors pertaining to the scarcity of man power, animal power, time and water during the ploughing period. These factors may collectively generate grounds which encourage or enforce small paddy farmers to adopt mechanical power despite they are not in a real position to afford.
\end{abstract}

\section{INTRODUCTION}

The transition from man power or animal power to mechanical power is popularly described as mechanization". Animal power, which had been the main source of farm power since the time of immemorial, has been rapidly displaced by mechanical power since the industrial revolution. At present, it is gradually being displaced even in developing countries. Although me-

1) For the purpose of this study, farm mechanization is defined as the introduction of tractors and power tillers into the tillage operation on wet paddy fields. Tractor is defined as four-wheeled traction engine of 35-45 HP fitted with tine tiller and cage wheels; and power tiller is defined as two wheeled traction engine of 6-7 HP fitted with rotavator and mud wheels. 
chanical power entered the paddy fields somewhat latter, it has already dominated a considerable share of the world's total paddy extent. Paddy cultivation in developing countries is under small farmers whose income is relatively low, and the paddy farming community is characterized by labour abundance and capital scarcity. Since the mechanical power is inherently labour saving and capital intensive, its irrelevancy to the paddy farming communities in developing countries has often been mentioned. And also, its private costs and benefits to small farmers do not seem to provide effective economic incentives. Nevertheless, mechanization appears to continue. It seems quite difficult to identify rational grounds for small paddy farmers' propensity to substitute mechanical power for animal draught power ${ }^{2}$. However, it is the objective of this study.

\section{Background of the Study Area}

Sri Lanka is an island of 25,000 squre miles which has a population of 14.8 milion, currently increasing at $2 \%$ per year. Agriculture is the important sector in the economy which accounts for one third of the GDP; 75-80 percent of the exports and 50-60 percent of the total employment. While tea, rubber, coconut and gems are the main exports, total rice production is absorbed domestically for consumption. Rice is essentially a small holders' crop because the major portion of $(78.92 \%)$ the national paddy extent is in holdings sized from one acre to less than ten acres (Table 1). Since the average paddy yield is also relatively low (42 bushels per acre), majority of farmers do not produce rice enough to meet their own family needs. It was estimated that $60 \%$ of paddy cultivating households do not produce adequate rice to meet their family needs, and there may be a further proportion who are just self-sufficient and have little or no surplus's). Therefore, the total domestic rice production is insufficient to meet the demand and about 25-30 percent of the local demand is met by rice importation.

Lack of marketable surplus together with the lack of employment opportunities in the non-agricultural sector (Table 2) keep the average farm household income at a considerably low level. Although national scale average data concerning farm household income and expenditure are not available, data gathered from a number of micro-level case studies indicate that the household income is hardly adequate to meet even their own basic needs (Table 3).

On the other hand, under the prevailing prices of tractors and power tillers and also under increasing prices of fuel, aquisition and maintenance of tractors and power tillers appear to be far beyond the average farmers' capacity. Nevertheless, number of tractors and power tillers has been continuousely rising ever since the introduction of mechanical power in $1950 \mathrm{~s}$ (Figure 2) and; the paddy extent ploughed by mechanical power has reached

2) In this case, buffaloes of swampt type (Bubalus Bubalis) of which liveweight rarely exceeding $320 \mathrm{~kg}$.

3) Moore, M. P. 1980 


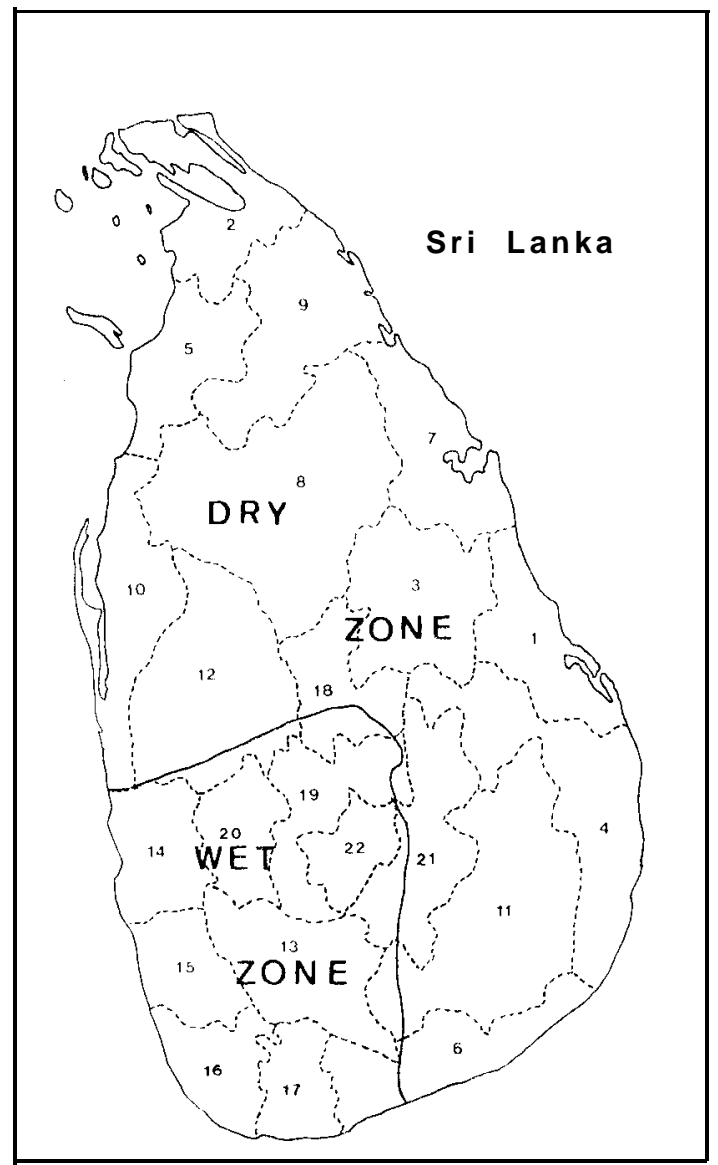

Fig. 1 Sri Lanka-Agroclimatic zones and district boundries.

Note; Agroclimatic zones were demarcated on the basis of the effective dry period according to Mandfred Domros, 1974

All administrative districts were numbered according to the districts' names given in table 4.

approximately $50 \%$ level of the total paddy extent. In Japan, the process of farm mechanization has been motivated by the apparent economic forces such as increased labour wage rates and the availability of employment opportunities in the non-farm sector. While the first factor created the need of farm machines as a substitute for labour, the second factor created the purchasing power by providing extra income from non-farm jobs. Thus, the combination of need and purchasing power generated the effective demand for farm machines, mainly for power tillers. In Sri Lanka, despite the absence of these both factors: increased labour wage rates and availability of employment opportunities in the non-farm sector, farm mechanization is in progress. Overall demand for mechanical farm power units, mainly for tractors gene- 
Table 1 Distribution of Paddy Lands by Size of the Holdings in Sri Lanka

\begin{tabular}{|c|c|c|c|}
\hline Size Class of the Holdings & Extent of Paddy & $\%$ & $\underset{\%}{\text { Cumulative }}$ \\
\hline Less than 1 acre & 52,064 & 4.14 & 4.14 \\
\hline 1 to 5 acres & 536,084 & 42.62 & 46.76 \\
\hline 5 to 10 acres & 404,493 & 32.16 & 78.92 \\
\hline 10 to 25 acres & 177,867 & 14.14 & 93.06 \\
\hline 25 to 50 acres & 44,209 & 3.52 & 96.58 \\
\hline 50 acres and over & 42,972 & 3. 42 & 100.00 \\
\hline Total & $1,257,689$ & 100.00 & \\
\hline
\end{tabular}

Unit: Acres

Source: Census of Agriculture 1973, General Report, Department of Census and Statistics, Colombo.

Table 2 Employed Population Classified by Occupation (major groups) in Sri Lanka

\begin{tabular}{|c|c|}
\hline Group & 96 \\
\hline Professional, technical and related workers & 4.9 \\
\hline Administrative and managerial workers & 0.4 \\
\hline Clerical and related workers & 5. 1 \\
\hline Sales workers & 7.5 \\
\hline Service workers & 5.4 \\
\hline Agricultural, animal husbandry and forestry workers, fishermen and hunters & 48.8 \\
\hline Production and related workers, transport equipment operators and labourers & 25. 4 \\
\hline Workers not classified by occupation & 2. 5 \\
\hline
\end{tabular}

Source: Statistical Pocket Book, Department of Census \& Statistics, 1971, Colombo.

Table 3 Average Annual Farm Household Income, Average Annual Expenditure on Production and Average Amount of Cash Available for Subsistence in Four Locations in Sri Lanka.

\begin{tabular}{lccc}
\hline Locality & Total Income & $\begin{array}{c}\text { Expenditure on } \\
\text { Production }\end{array}$ & $\begin{array}{c}\text { Amount Available } \\
\text { for Subsistence }\end{array}$ \\
\hline 1. Pavatkulam & 7113.00 & 3747.00 & 3366.00 \\
2. Uda Walawe & 4356.80 & 2757.00 & 1599.80 \\
3. Kadulla & 6000.85 & 4039.10 & 1961.75 \\
4. Padaviya & 4428.00 & 3634.00 & 794.00 \\
\hline
\end{tabular}

Unit: Rupees

Source: 1. ARTI 1980 A Study of Five Settlement Schemes prior to Irrigation Modernization vol. Ill-Pavatkulam

2.3.4. Farrington, J. and F. Abeyratne, 1982 Farm Power in Sri Lanka pp. 203

Note; 1 rupee=9¥

ARTI, Agrarian Research and Training Institute, Colombo.

rated in the agricultural sector, still remains greater despite the widespread poverty among farmers. What are the factors which create the need and purchasing power for tractors and power tillers ? While the farm households' real income remains almost unchanged, some socio-economic factors have created the need for mechanical farm power but not the purchasing power. Purchasing power has been existing in the high-income category which con- 


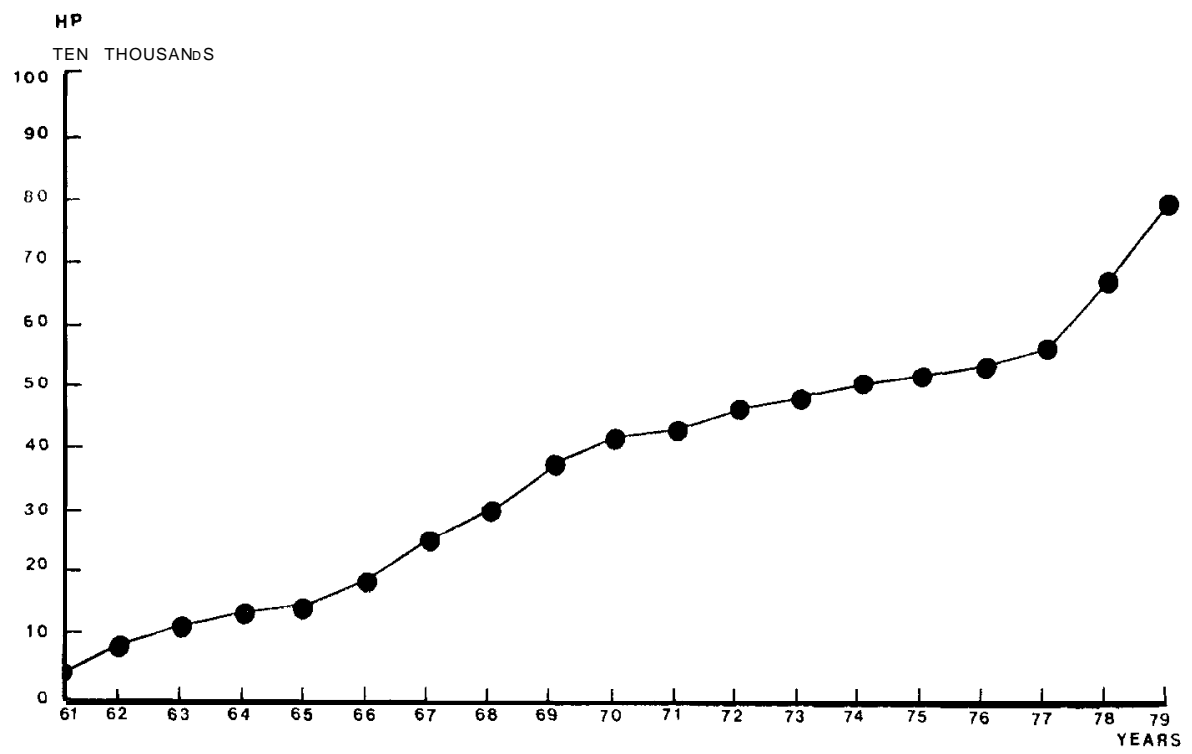

Fig. 2 Growth of mechanical farm power in Sri Lanka (1961-1979).

Note: Total available tractors and power tillers were converted into horse power. Tractor=40 HP, Power tiller=7 HP

Source: New Registration Records, Division of Statistics, Commissioner of Motor Traffic, Colombo.

sists of traders, local businessmen, land owners, some large farmers and owners of the large buffalo herds. Reacting to the growing need for mechanical farm power, the high income category, having realized the profitability of hiring out mechanical farm power to those who need it, made available the purchasing power. In consequence, the need came from farmers and the purchasing power came from high-income category collectively generated the effective demand for tractors and power tillers (Figure 3). Due to the greater capacity of tractors in undertaking a greater volume of custom

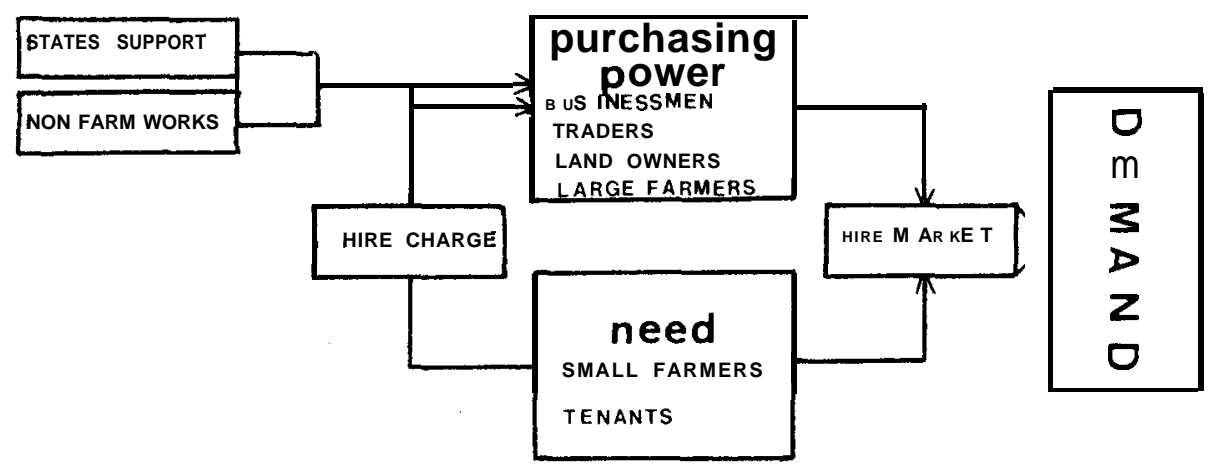

Fig. 3 Effective demand for mechanical farm power in Sri Lanka 
worlss, the potential mechanical farm power ownerspreferred tractors rather than power tillers. Therefore, in contrast to Japan, in Sri Lanka, farm mechanization was started with tractors, not with power tillers. Even now, tractors are preferred by power owners, because the profitability of tractor ownership is greater than that of power tiller ownership. However, the important point to be emphasized here is the existence of two seperate categories such as farm power owners and farm power users. As it is shown in figure 3 these two categories are met at the farm power hire market which is monopolized by the farm power owners. By virtue of their monopoly, farm power owners manage to pass on the increasing cost of machines, fuel, repairs, and spare parts to the farm power users by raising the hire rates. Therefore, the profitability of the farm power ownership remains unchanged and mechanization continues to proceed. As long as the profitability of farm power ownership remains unchanged, mechanization will continue to proceed putting its whole burden on farm power users. Although the state provides loans on easy terms for purchasing tractors and power tillers, aquisition of them still remains far beyond the small farmers' capacity. Therefore, these two categories such as farm power owners and farm power users will continue to function seperately.

Although it is the category of small farmers which bears the total cost of mechanization, they appear to continue unusually to depend on mechanical farm power, paying their hard-earned money to farm power owners. And also, any tendency of returning to the traditional less expensive animal power cannot be identified. What are the factors which enforce or encourage small farmers to continuously depend on hired mechanical power ? It has been observed that the scarcity of man power, animal power, time and water during the rather short ploughing peroid ${ }^{4)}$ generates compelling grounds to substitute mechanical power for animal power. Therefore, it is worthwhile to observe the validity of this contention at the national level. Hence the hypothesis to be tested here is:

scarcity of lahour, scarcity of draught animal power, and the scarcity of time and water in the ploughing period explain farmers' propensity to substitute mechanical farm power for animal farm power.

To be more precise, the main hypothesis can be divided as follows:

$i$. As the scarcity of hired labour required for buffalo ploughing increases, farmers' propensity to substitute mechanical farm power for animal farm power increases.

ii. As the scarcity of animal power increases, farmers' propensity to substitute mechanical farm power for animal farm power increases.

iii. As the scarcity of water and time required for animal ploughing increases, farmers' propensity to substitute mechanical farm power for animal farm power increases.

This paper is intended to test these hypotheses.

4) Ploughing period generally varies from 30-40 days. 


\section{METHODOLOGY}

As a matter of fact, time-series data are required to observe a transitional process. Since the mechanization, by clefinition, is a transitional process, time-series data are required to test the above formulated hypotheses; but unfortunately comparable time-series data with regular intervals are not available. Therefore, the next possible alternative, cross-sectional data were used. It was felt that the best way to test the above formulated hypotheses is to regress the degree of mechanization on the explanatory variables which represent the scarcity of hired labour, animal power, water and time for ploughing operation of paddy cultivation; and to estimate their total explanatory power in explaining the variation of the dagree of mechanization. Degree of the usage of mechanical farm power can be quantified either as a number of mechanical power units per unit area or as a percentage of paddy extent ploughed by mechanical power per unit area. Since the majority of tractors and power tillers are owned by non-farmers, a considerable proportion of the total used hours was found to be attracted by non-farm works, for instance heavy transport, construction works etc . Therefore, the first operational definition does not really indicate the degree of mechanization. Hence the second has been adopted. Therefore, nationwide district-wise (22 districts) data on the percentage of paddy extent ploughed by mechanical power were taken to quantify the degree of paddy land mechanization, and it has been treated as the dependent variable. Assuming that the buffalo operators' wage rates are determined by the demand and supply, district-wise data on buffalo operators' wage rates prevailing in the ploughing period were taken to quantify the scarcity of labour. The scarcity of animal power too has been simply quantified by calculating the number of buffalo pairs per acre (buffalo density) in all districts. In contrast to first and second explanatory variables, the third one, scarcity of time and water was felt to be extremely difficult to quantify. However, in the light of many village level case studies and the authors' field experience, it can be assumed that water and time available for tillage operation are considerably constrained in major irrigation schemes than elswhere due to the strictly time-schedulled cultivation calendar and the restrictions over the water issues during the ploughing period. Therefore, percentage of the paddy extent under major irrigation schemes in all 22 districts were taken to quantify the scarcity of time and water. Thus, the variables used in the analysis are as follows :

Y Percentage of paddy extent ploughed by tractors and power tillers.

$X_{1}$ Buffalo operators' wage rates per day during the ploughing period

$X_{2}$ Number of buffalo pairs per every asweddumised $d^{6)}$ acre.

5) Farrington, J. and F. Abeyratne 1932

6) Asweddumised land is a paddy land, commonly though not necessarily irrigated, which is levelled and bunded to facilitate the impounding of water. 
$\mathrm{X}_{3}$ Percentage of paddy extent under major irrigation schemes". Therefore, the operational definitions for the hypotheses are:

As the buffalo operators' wage rates prevailing in the ploughing period increases, percentage of the paddy extent ploughed by the mechanical power increases.

As the number of buffalo pairs per acre (buffalo density) increases, percentage of the paddy extent ploughed by the mechanical power decreases. As the percentage of the paddy extent under major irrigation schemes increases, percentage of the paddy extent ploughed by the mechanical power increases.

According to the main hypothesis, it is the combination of the all three factors, rather than any single one, which explains the farmers' propensity to substitute mechanical power for animal power. Therefore, assuming that there is no interaction among these three variables, $\mathrm{Y}$ was regressed on $X_{1}$, $X_{2}$ and $X_{3}$ in order to test the hypothesis.

The model is,

$$
Y=a+b_{1} X_{1}+b_{2} X_{2}+b_{3} X_{3}+u
$$

Apart from the selected three explanatory variables, four more variables were found to have correlation with the dependent variable. Due to the observed correlation between them, and their lack of direct impact on the dependent variable, they were not included into the model; but since it was felt that those variables were helpful to explain the observed correlation between the dependent variable and each explanatory variable, they have been attached to the appropriate explanatory variables at the supplementary level as follows.

$X_{1}$ Buffalo operators' wage rates

$X_{1 a}$ Population density

$X_{1 b} \quad$ Size of paddy holdings

$X_{2}$ Buffalo density

$X_{2 a}$ Decrease in buffalo density during the period from 1960-1976

$X_{2 h}$ Increase in paddy extent in all individual districts as percentage values of the national growth of paddy extent during the period from 1961-1980

$X_{3}$ Percentage of paddy extent under major irrigation schemes.

In addition to these marco-level data (Table 4), some microlevel data assembled from village level field surveys and from a number of published village level case studies were used in providing explanations for the observed correlations.

\section{RESULTS AND DISCUSSION}

From the table 5, it will be noticed that the correlation between the explanatory variables is negligible, and therefore it can be assumed that they

7) Major irrigation schemes are the irrigation works from which the issues and distribution of water is controlled by the bureaucracy. 
Table 4 District-wise Data for All Variables Given in the Correlation Matrix

\begin{tabular}{|c|c|c|c|c|c|c|c|c|}
\hline & $X_{1}$ & $X_{1 a}$ & $X_{1 b}$ & $X_{2}$ & $X_{2 a}$ & $X_{2 b}$ & $X_{3}$ & $Y$ \\
\hline 1. Batticaloa & 35.56 & 125 & 4.65 & 0.02 & ti6.66 & 9.60 & 28 & 73.63 \\
\hline 2. Jaffna & 26.67 & 394 & 1. 31 & 0.02 & 33.33 & 1.99 & 32 & 85.58 \\
\hline 3. Polonnaruaa & 26.00 & 57 & 2.58 & 0.17 & 43.33 & 6. 24 & 87 & 27.11 \\
\hline 4. Ampara & 25.00 & 109 & 3. 43 & 0.04 & 63.63 & a. 05 & 75 & 74.38 \\
\hline 5. Mannar & 30.00 & 44 & 2.94 & 0.03 & 50.00 & 3.14 & 74 & 89.65 \\
\hline 6. Hambantota & 25.00 & 153 & 1.63 & 0.17 & 22.72 & 0.00 & 66 & 59.79 \\
\hline \multirow{3}{*}{ 7. Trincomalee } & 40.00 & 88 & 3.08 & 0.08 & 57.89 & 7. 47 & 49 & 83.49 \\
\hline & 26.67 & 66 & 1. 51 & 0.08 & 50.00 & 18.24 & 47 & 73.33 \\
\hline & & 26 & 3.27 & 0.01 & 50.00 & 5.92 & 34 & 98.18 \\
\hline 10.8. Anuradhapura Puttalam & 61.6720 .00 & 151 & 1.33 & 0.09 & 43.75 & 1.74 & 24 & 55.35 \\
\hline 10. Mvonimaragala & 23.89 & 33 & .321 & 0.14 & 54.83 & 2.87 & 30 & 23.42 \\
\hline 12. Kurunegala & 25.81 & 284 & 0.73 & 0.29 & 17.14 & 7.45 & 17 & 27: 03 \\
\hline 13. Ratnapura & 28.13 & 233 & 0.80 & 0.08 & 71.42 & 7. 80 & 56 & 12.73 \\
\hline 14. Colombo & 3122 & 1773 & 0.65 & 0.10 & 23.07 & 2. 48 & 12 & 6.30 \\
\hline 15. Kalutara & 25: 00 & 512 & 0.66 & 0.08 & 33.33 & 2. 21 & 00 & 1. 41 \\
\hline 16. Galle & 27.33 & 495 & 0.68 & 0.02 & 50.00 & 1.88 & 00 & 1. 14 \\
\hline \multirow[t]{2}{*}{ 17. Matara } & 25.00 & 541 & 0.69 & 0.04 & 20.00 & 1.61 & $16^{\prime}$ & 15.35 \\
\hline & 38.34 & 181 & 0.78 & 0.28 & 37.77 & 2.69 & 27 & 20.53 \\
\hline 18. Mlatalke & 20.33 & 553 & 0.63 & 0.18 & 10.00 & 2.82 & 20 & 4.99 \\
\hline 20. Kegalle & $24: 50$ & 438 & 0.45 & 0.21 & 4. 54 & 0.46 & 00 & 0.16 \\
\hline 21. Badulla & 40.00 & 238 & 0.64 & 0.05 & 66.66 & 5.63 & 34 & 4.43 \\
\hline 22. N'Eliya & 20.00 & 384 & 0.57 & 0.17 & 22.72 & 0.00 & 08 & 2.36 \\
\hline
\end{tabular}

Unit: $X_{1}=$ rupees $\quad X_{1 a}=$ persons/sq. mile $\quad X_{1 b}=$ acres $\quad X_{2}=$ pairs (buffalo) $X_{2 a}, X_{2 b}, X_{3}, Y=$ percentage

Source : $X_{1}, \quad$ Price and Wage Statistics, Central Bank of Ceylon, 1980, Colombo.

$X_{1 a}$, Department of Census and Statistics, 1980, Colombo.

$X_{1 b}$, Department of Census and Statistics, Census of Akriculture, 1973, Colombo.

$X_{2}$, Land Tenure Data-Sri Lanka, Rural Institutions and Agricultural Productivity, Ministry of Agriculture and Lands, 1976, Colombo.

$X_{2 a}$ Buffalo Poulation in 1976; Land Tenure Data-Sri Lanka, Rural Institutions and Agricultural Productivity, Ministry of Agriculture and Lands, 1976, Colombo.

Paddy Extent in 1960 and 1976; Paddy Statistics, Department of Census and Statistics, Colombo.

$\mathbf{X}_{2 b}$, Paddy Extent in 1961 and 1980; Paddy Statistics, Department of Census and Statistics, Colombo.

$X_{3}$, Paddy Statistics, Department of Census and Statistics, 1980, Colombo.

$Y$, Estimated Area by Method of Preparation of Land by Districts, 1979/80 Maha; Depatment of Census and Statistics, Colombo.

Note: For district boundries, see figure 1

$\mathrm{X}_{2 a} ; \boldsymbol{a}=$ Buffalo density in 1960

$b$-Buffalo density in 1976

$$
\underset{a}{(a-b) \times 100}-X^{* a}
$$

$X_{2 b} ; \mathbf{a}=$ Increase of the paddy extent in each district from 1961-1980

A=Increase of the total national paddy extent from 1961-1980

$$
\frac{a \times 100}{\mathrm{~A}}=X_{2 b}
$$

are more or less independent.

The parameters for equation are estimated as follows,

$$
\mathrm{Y}=1.8982+1.0398 X_{1}-120.6976 X_{2}+0.6711 X_{3}^{* *}
$$

$$
\text { (1.6009) (1.6535) (2.9235) }
$$


The $t$ values of each parameter are given within brackets and the sign of double asterisks (**) indicates the significance at $1 \%$ level.

The multiple correlation coefficients $\mathbf{R}$, which measures the degree of association between three independent variables and the dependent variable, has a value of 0.7144 . Thus the three independent variables together explain $\left(R^{2}\right), 51$ percent of the variation in the dependent variable. Furthermore, the signs of the regression coefficients are as hypothesized. This figure indicates that 51 percent of the mechanization of the ploughing operation is associated with factors pertaining to labour wage rates, buffalo density and the percentage of paddy extent under major irrigation schemes.

Table 5 Matrix for Simple Correlation Coefficients for All Variables

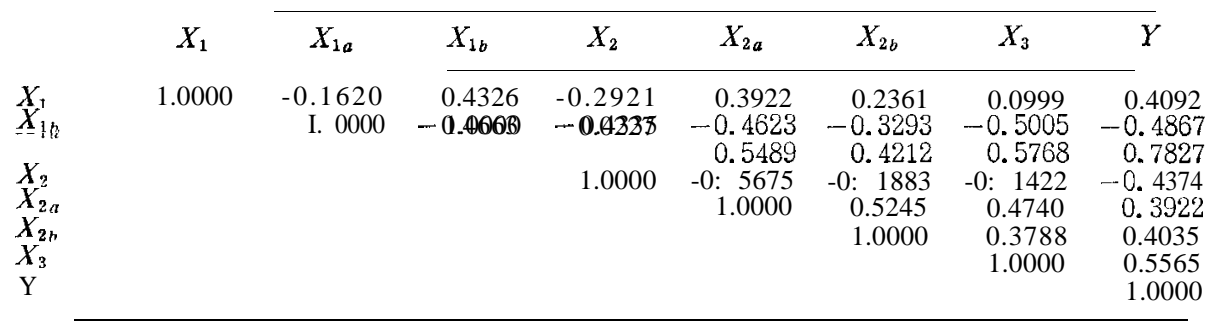

For the sake of simplicity and brevity, and also to be consistent with the hypotheses, discussion will be done under following themes.

1. As a substitute for man power (hired labour)

2. As a substitute for animal power (buffaloes)

3. As a substitute for time and water

\section{As a substitute for man power (hired labour)}

Sri Lankan paddy farming society is, in general terms, a labour surplus economy, but due to the seasonality associated with labour demand, the labour situation here is characterized by the so-called "scarcity in surplus". The main source of labour for paddy farming has been the family labour of which the supply remains almost unchanged throughout the year while the labour requirement fluctuates seasonally. The labour requirement rises to its maximum during ploughing and harvesting periods. The greater labour requirement during the ploughing period is accounted for by the greater number of man days required for animal ploughing (Table 6). When the capacity of the family labour force becomes inadequate to meet the requirement during the peak periods, the probable labour shortage was solved in old days by the mutual exchange of labour which is called attama. Under this tradition, farmers managed to plough their paddy fields by animal draught power without any cash costs on hired labour, because each farmer offered their own laboul to their fellow farmers in return for the labour they received from them. Social cohesion, inter-personal trust, and higher values they kept on the social institutions such as family, kinship and neighbourhood which provided the basis for attama have undergone serious changes since recently. In con- 
Table 6 Labour Requirement for Alternative Sources of Farm Power in Sri Lanka

\begin{tabular}{cccc}
\cline { 3 - 3 } Animal Power & \multicolumn{2}{c}{ Mechanical Power } \\
4.0 & Power tillers & Tractors \\
\cline { 2 - 3 } & 1.0 & 0.5 \\
\hline
\end{tabular}

Unit: Man days/Acre

Source : Field survey conducted by R. Ulluwishewa, 1982 in Hureegama.

sequence, the attamahas seased to exist in many areas except some remote isolated localities. However, its apparent consequence is the labour shortage in peak periods. If the labour shoratage is the only problem, the immediate rational solution is the adoption of a labour-saving technology. In this context, it is the mechanical farm power. Under the previous system, attama had organized the available limited labour time in such a way that every farm householder could use his labour more intensively for the benefit of the whole community. Therefore, every one could receive required labour in time. At present, in the absence of such an organized institution, no one is obliged to offer one's labour, even for cash payment, when it is needed by another. Therefore, now the farmers find it difficult to assemble labourers when they are in really need of them. Timely labour supply is very crucial for paddy cultivation because any delay in ploughing will cause heavy damages. The troubles and difficulties involved in assembling labourers appear to favour mechanization. It is evident in some dry zone new settlements that farmers get labourers from very distant areas during the peak periods in which case they have to bear the extra cost on food and accommodation for migrated labourers ${ }^{8)}$. It has been observed in some village level case studies that the high labour component in the use of animal power is a major reason for the high cost incurred in the usage of animal power in some areas ${ }^{9}$.

However, the important fact to be emphasized here is when and where the cost difference between the animal power and mechanical power becomes smaller, mechanical power becomes more attractive because under such a situation, farmers are likely to forgo the little cost advantage associated with animal power for the sake of convenience associated with mechanical power. On this ground, it can be assumed that the labour scarcity during the ploughing period favours mechanization ; and the positive correlation coefficient between the buffalo operators' daily wage rates during the ploughing period and the percentage of paddy extent ploughed by mechanical power $(r=0.4092)$ provides evidence for the validity of this hypothesis.

The supplementary variables, population density and the average size of paddy holdings have indirect impacts on labour situation. The supply of hired labour in traditional societies depends on the individual's consent, and the need to work as hired labourers. The consent and need are conditioned

४) Crooks, G. R. and II. A. Ranbanda 1981 .

9) ARTI, 1980 . 
by the degree of landlessness, the need for supplementary income for subsistence and the socio-economic status of the person. However, the majority of the full time hired labourers come from the landless category, because in the absense of non-farm jobs they have no alternatives but to sell their labour within the agricultural sector. It is reasonable to assume that where the population density is high, landless population is also high and therefore labour supply is favourable. Hence, farmers in less populated areas, may tend to use mechanical power due to the labour shortage; and the negative correlation coefficient $(\boldsymbol{r}=-0.4867)$ between the population density and the dependent variable suggests the same tendency. The second supplementary variable, the size of paddy holdings appears to have implications with labour demand. If the size of paddy holding is too large, the rising labour requirement exceeds the capacity of the family labour force. It generates the demand for hired labour. Therefore, in order to avoid the probable labour shortage, large farmers are likely to use mechanical power. As it was hypothesized, the correlation coefficient between the size of paddy holdings and the percentage of paddy extent ploughed by mechanical power was found to be positive ( $r=0$. 7827). However, in Sri Lanka the spacial variation of the size of paddy holdings somewhat coincides with the spacial variation of population density in negative way. As it is shown in the matrix for simple correlation coefficients for all variables, population density appears to have considerable impact on the dependent variable. Therefore, the observed high positive correlation between the size of paddy holdings and the dependent variable does not necessarily mean that the size of paddy holdings is so significant in explaining the variation in degree of mechanization. Therefore, although the size of paddy holdings has a significantly high positive correlation with the dependent variable, it is treated here marely at the supplementary level.

\section{As a substitute for animal power (buffaloes)}

It has been observed in a number of micro-level socio-economic surveys that although the small farmers are well aware of the cost advantages associated with the usage of buffalo power for ploughing, some of them depend on mechanical power due to their lack of access to buffalo power (Table 7).

'Table 7 Reasons for the Preference of Mechanical I'loughing in Declining Order of Importance in Unagaswewa Village in Sri Lanka

\begin{tabular}{|c|c|c|c|c|c|c|c|}
\hline & Timeli- & $\begin{array}{l}\text { Conveni- } \\
\text { ence }\end{array}$ & $\begin{array}{c}\text { Buff alo } \\
\text { Shortage }\end{array}$ & $\begin{array}{c}\text { Shortage of } \\
\text { Trained } \\
\text { Buffaloes }\end{array}$ & $\begin{array}{l}\text { Share-crop- } \\
\text { ping Agree- } \\
\text { ments with } \\
\text { Tractor } \\
\text { Owners }\end{array}$ & $\begin{array}{c}\text { Demons- } \\
\text { trative } \\
\text { Effect }\end{array}$ & $\begin{array}{c}\text { “ ; : ; : ; “ }, \\
\text { Buffalo } \\
\text { Operators }\end{array}$ \\
\hline $\begin{array}{l}1^{\text {st }} \text { Reason } \\
2^{\text {nd }} \text { Reason } \\
3^{\text {rd }} \text { Reason }\end{array}$ & $\begin{array}{l}5 \\
8 \\
4\end{array}$ & $\begin{array}{l}4 \\
6 \\
5\end{array}$ & $\begin{array}{l}1 \\
2 \\
6\end{array}$ & $\begin{array}{l}6 \\
2 \\
2\end{array}$ & $\begin{array}{l}4 \\
0 \\
1\end{array}$ & $\begin{array}{l}0 \\
2 \\
1\end{array}$ & $\begin{array}{l}0 \\
0 \\
1\end{array}$ \\
\hline
\end{tabular}

Unit: Number of farmers reporting . $N=20$

Source: Field Survey conducted by R. Ulluwishewa, 1982. 
Therefore, when and where the available buffalo population is inadequate to meet the demand, farmers may be anticipated to use mechanical power. When the size of the national buffalo herd and its total operational capacity is taken into consideration, it seems that the total operational capacity (at the performence rate of 0.25 acre/one day/buffalo pair) is considerably greater than the requirement, even if the total national paddy extent is ploughed by buffaloes. Although it is shown in the table 8 that the available buffalo population is in excess of the national requirement, it is not necessarily to be so because there are some districts of which the available buffalo power is insufficient to meet the requirement (table 9). In addition, as it has been found in Udawalawe and Padaviya that the buffalo ownership pattern which is characterized by a few owners keeping large buffalo herds, substantially reduces the small farmers' access to buffalo power ${ }^{10)}$. Further more, under such an ownership pattern, the available buffalo power can hardly be utilized intensively due to the difficulties involved in arranging full work programmes for large herds. In contrast, as it was observed in Hureegama $^{11}$ that the widespread ownership of small number of animals per owner considerably improves the small farmers' access to buffalo power. If almost all small farmers hold one or two working buffaloes, they could be pooled and used on each farmer's paddy field rotationally. Lack of trained buffaloes and experienced buffalo operators were also found to constrain the farmers' access to buffalo power ${ }^{12}$ (Table 7). After the introduction of tractors, having realized the greater profitability of tractor ownership, some business-oriented buffalo owners who maintained large buffalo herds, tended to abandon or sell their animals and purchased tractors. Most of the sold buffaloes were believed to be slaughtered. It is not a tradition in the buddhist society in Sri Lanka, to slaught animals which once served. Therefore, when those animals became unnecessary, what the owners easily did was to let them live in adjacent jungles or in the homesteads. However since the ownership remained in the hands of former owners. the buffaloless small

Table 8 Total Buffalo Population and its Operational Capacity in Sri Lanka

\begin{tabular}{|c|c|c|c|c|c|c|}
\hline \multirow[b]{2}{*}{$\begin{array}{r}\text { Total } \\
\text { Buffalo }\end{array}$} & \multirow{2}{*}{$\begin{array}{l}\text { A } \\
\text { Working } \\
\text { Population }\end{array}$} & \multirow{2}{*}{$\begin{array}{c}\text { B } \\
\text { Operational } \\
\text { Capacity }\end{array}$} & \multirow{2}{*}{$\begin{array}{c}\text { C } \\
\text { Total Paddy } \\
\text { Extent }\end{array}$} & \multicolumn{3}{|c|}{$\begin{array}{c}\text { D } \\
\text { Excess }\end{array}$} \\
\hline & & & & in & $\begin{array}{l}\mathrm{D}_{1} \\
\text { Operational } \\
\text { Capacity }\end{array}$ & $\begin{array}{c}\mathrm{D}_{2} \\
\text { in Buffalo } \\
\text { Pairs }\end{array}$ \\
\hline \multicolumn{2}{|c|}{181338} & 1813380 & 1689241 & & 2413.9 & 1241.39 \\
\hline
\end{tabular}

Unit: A-pair (buffalo) $\mathrm{B}, \mathrm{C}, \mathrm{D}_{\mathrm{t}}=$ acres

Source: A and C; Land Tenure Data Sri Lanka, 1976, Rural Institutions and Agricultural Productivity, Ministry of Agriculture and Lands, Colombo.

Note: $\mathrm{A} \times 10$ (operational capacity of a buffalo pair per ploughing period; 40 days) $=\mathrm{B}$

$$
\mathrm{B}-\mathrm{C}=\mathrm{D}_{1} \quad \mathrm{D}_{1} / 10=\mathrm{D}_{2}
$$

10) Farrington, J. and F. Abeyratne 1982.

11) Ulluwishewa, R., and K. Tsuchiya 1983.

12) Field survey conducted by R. Ulluwishewa in Unagaswewa village, 1982. 
Table 9 Excess/Shortage of the Buffalo Farm Power by District in Sri Lanka 1976

\begin{tabular}{|c|c|c|c|c|c|}
\hline \multirow{2}{*}{ District } & \multirow{2}{*}{$\begin{array}{c}\text { A } \\
\text { Working } \\
\text { Buffalo } \\
\text { Population }\end{array}$} & \multirow{2}{*}{$\begin{array}{c}\text { Operational } \\
\text { Capacity }\end{array}$} & \multirow{2}{*}{$\begin{array}{c}\text { C } \\
\text { Total } \\
\text { Paddy } \\
\text { Extent }\end{array}$} & \multicolumn{2}{|c|}{$\begin{array}{l}\text { D } \\
\text { ge of Opacity }\end{array}$} \\
\hline & & & & In $\stackrel{\mathrm{D}_{1}}{\mathrm{Acres}}$ & $\begin{array}{c}\mathrm{D}_{2} \\
\text { In Number of } \\
\text { Buffalo Pairs }\end{array}$ \\
\hline Colombo & 7204,0 & 72040 & 70342 & 1698 & 169.8 \\
\hline Kalutara & 4829.5 & 48295 & 56950 & -8655 & -865.5 \\
\hline Galle & 1819.5 & 18195 & 62772 & -44577 & -4457.7 \\
\hline Matara & 2451.0 & 24510 & 53237 & -28727 & -2872.7 \\
\hline Kegalle & 6233.0 & 62330 & 29469 & 32861 & 3286.1 \\
\hline Ratnapura & 5624.5 & 56245 & 63187 & -6942 & -694.2 \\
\hline Kandy & 9296.5 & 92965 & 50585 & 42380 & 4238.0 \\
\hline N'Eliya & 3305.5 & 33055 & 19385 & 13670 & 1367: 0 \\
\hline Kurunegala & 53311.5 & 533115 & 179160 & 353955 & 35395.5 \\
\hline Matale & 10656.0 & 106560 & 36826 & 69734 & 6973.4 \\
\hline Badulla & 2238.0 & 22380 & 42899 & -20519 & -2051.9 \\
\hline Puttalam & 4204.5 & 42045 & 45462 & -3417 & -341.7 \\
\hline Moneragala & 4033.0 & 40330 & 27295 & 13035 & 1303.5 \\
\hline Jaffna & 2108.5 & 21085 & 90217 & -69132 & -6913.2 \\
\hline Vavnia & 1188.0 & 11880 & 80362 & -68482 & -6818.2 \\
\hline Mannar & 1908.0 & 19080 & 53377 & -34297 & -3429.7 \\
\hline Anuradhapura & 17940.5 & 179405 & 224080 & -44675 & -4467.5 \\
\hline Polonnaruwa & 15156.5 & 151565 & 88550 & 63015 & 6301.5 \\
\hline Trincomalee & 7207.0 & 72070 & 82200 & -10130 & -1013.0 \\
\hline Baticaloa & 3601.0 & 36010 & 129159 & -93149 & -9314.9 \\
\hline Amparai & 7495.5 & 74955 & 150122 & -75167 & -7516.7 \\
\hline Hambantota & 9226.5 & 92265 & 53605 & 41650 & 4166: 0 \\
\hline
\end{tabular}

Source: See under Table 8

Note: See under Table 8

farmers were not permitted to use them. In some cases, small farmers were reported to be intimidated to prevent them from developing their own small buffalo herds. Its net result was, when farm power owners shifted from animal draught power to mechanical power, farm power users or in other words non-power owners had no alternatives but to hire mechanical power ${ }^{13}$. At present, the remaining buffaloes still available in some areas, cannot be used for ploughing operation because they are not trained for working on paddy fields. When all these factors were boiled down into one, it suggests that the number of buffalo pairs available per unit area does not adequately indicate the small farmers' lack of access to buffalo power. Nevertheless, the observed negative correlation $(r=-0.4374)$ between the buffalo density and the dependent variable suggests that when and where the available buffalo draught power is in short, farmers are likely to hire mechanical power for ploughing.

Since the national independence, the accepted strategy to raise the national rice production has been the expansion of land under paddy by renovating the abandoned irrigation reservoirs and constructing the new multipurpose irrigation projects. Therefore, in some districts the extent of land under paddy has remarkably increased, and the increasing rate of paddy ex.

13) Field survey conducted by R. Ulluwishewa in Unagaswewa village, 1982. 


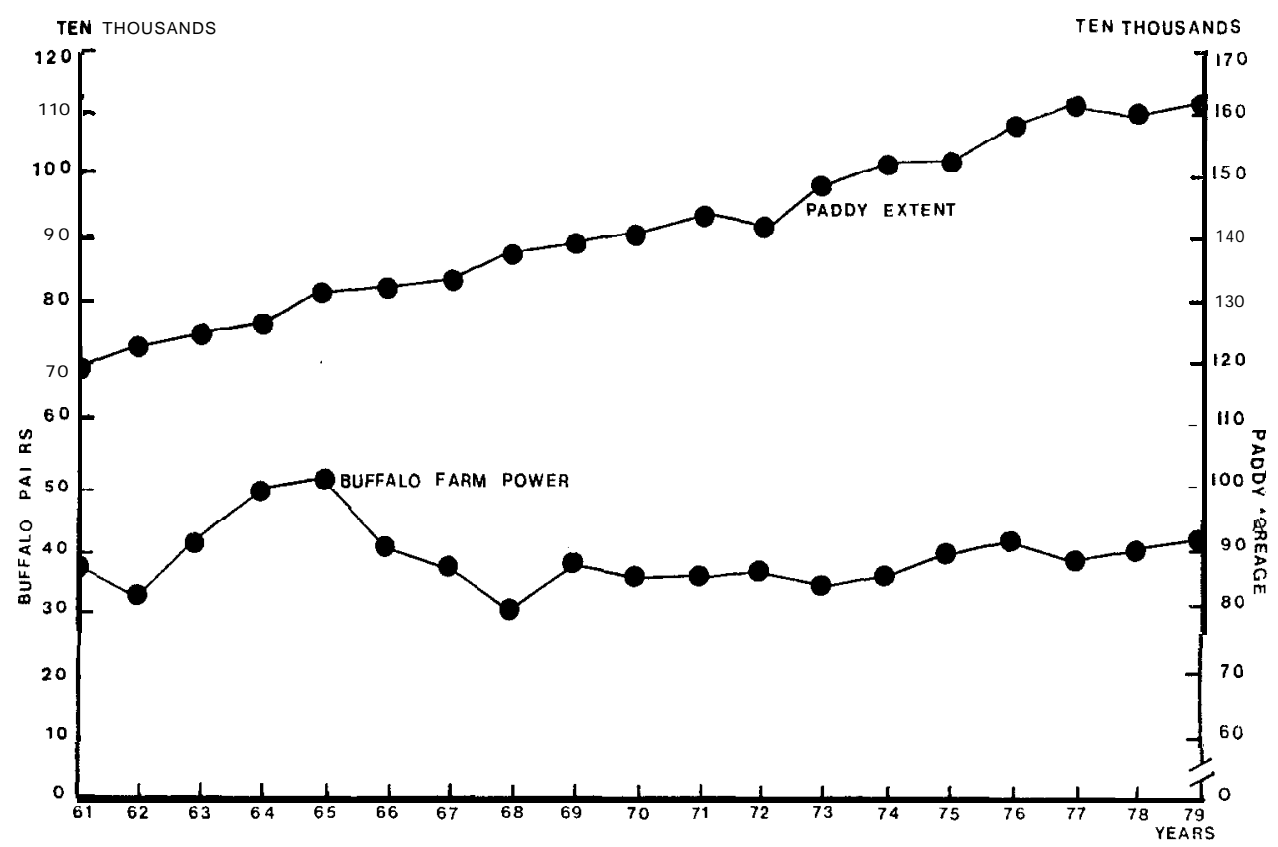

Fig. 4 Growth of national paddy extent and buffalo population in Sri Lanka (1961-1979)

Source: Paddy Statistics and Livestocks Statistics, Deparment of Census and Statistics, Colombo.

tent exceeded the increasing rate of buffalo population (Figure 4). Its inevitable consequence was the farm power shortage. Since the animal power cannot be increased suddenly, the apparent immediate solution was the mechanization. If the paddy extent in an area increases while the buffalo population remains more or less constant, the buffalo density in that area moves downward; and farmers in that area are likely to move towards mechanization. This assumption is supported by the observed positive correlation ( $r=$ $0.3922)$ between the decrease in buffalo density during the period from 1960 to 1976 ( $X_{2 a}$ supplementary variable) and the degree of mechanization. Impact of the increase in paddy extent on farmers' tendency towards mechanization is further clarified by the observed positive correlation between the increase in paddy extent in all individual districts during the period from 1961 to 1980 as perentage values of the national growth of paddy extent during the same period (supplementary variable $X_{2 b}$ ) and the degree of mechanization ( $r=0$. 4035). These both results suggest that when the paddy extent expands rapidly, farmers tend to use mechanical power for ploughing in order to overcome the farm power shortage.

\section{As a substitute for time and water}

As far as the number of hours required for ploughing operation is con- 
Table 10 Operational Capacity of Alternative Farm Power Sources in Sri Lanka

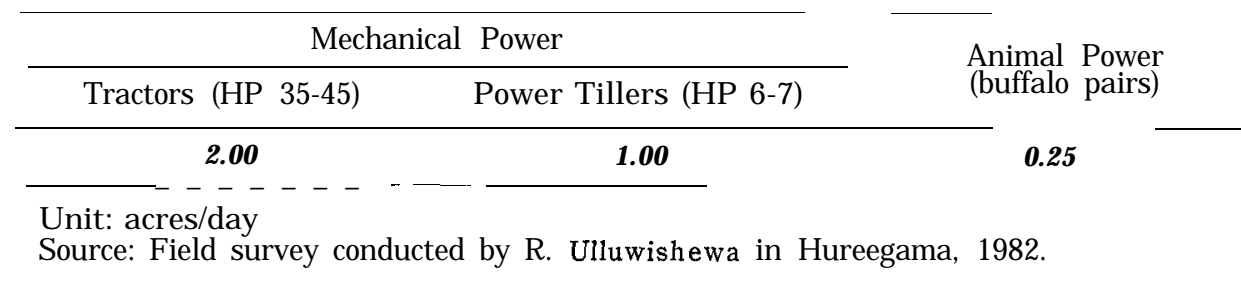

cerned, the mechanical power is obviously superior to the animal power (Table 10). Therefore, when and where the timeliness becomes crucial, mechanical power is likely to be preferred. However, if the supply of mechanical power is inadequate to meet the demand, the waiting time for tractors may counterbalance the speediness of operation. Hence, it is safe to assume that where and when the timeliness of ploughing operation becomes crucial, mechanical power is preferred if it is timely available. In any area, delay in ploughing leads to delay in sowing and harvesting too. So, the late starters cannot stay in consistent with seasonal rains. For instance, if a late starter fails to harvest before the beginning of the second rainy season, it will cause heavy losses. Losses caused by birds at the harvesting period become more severe to late starters because once all fellow farmers harvested all the rice-eating birds gather to the remaining unharvested farm. The damages caused by late ploughing are more severe if the water supply for paddy cultivation depends on irrigation. In such a case, the water issues are time-schedulled. Therefore, all the farmers have to stay in consistent with the pre-planned cultivation calendar, and those who fail to do so, have to face damages caused by water excess or shortage. Each paddy yaya ${ }^{14)}$ has different cultivation calendar which was prepared by the meeting (Kanna meeting) attended by all the farmers who cultivate in that particular yaya. This meeting is held just before the commencement of the cultivation season. In small tank villages (minor irrigation schemes) the pre-setup dead lines for water issues are implemented by the tract leader, a farmer, elected by the vote of all the farmers, while in the major irrigation schemes it is done by an irrigation engineer who is appointed by the state. $\mathrm{He}$ is responsible directly to the state not to the farmers whereas the tract leader is responsible to his fellow farmers. Therefore, he is obliged to be considerate with individual's problems. It has been observed in small tank villages that the pre-setup dead lines for water issues are not always strictly implemented ${ }^{15)}$. Therefore, even late starters are likely to be able to avoid at least a part of the potential losses but in the case of major irrigation schemes it seems to be rather difficult or impossible because the irrigation engineers, in general, work to the rule. Their lack of experience in farming and their poor understanding in farmers' way of thinking and problems too, make them strict ${ }^{16)}$.

14) An irrigated tract of land, comprising several farms.

15) Ulluwishewa, R. and K. Tsuchiya 1983 
Therefore, in major irrigation schemes, any delay in ploughing operation would most probably cause heavy losses. Although the relationship between the delay in ploughing and the losses can hardly be expressed in quantitative terms, if the buffalo power is used on large scale farms in major irrigation schemes, the cost advantages associated with buffalo power may be counterbalanced by the losses caused by delay. Since the density of mechanical power was observed to be high in the major irrigation schemes in the dry zone $\mathrm{e}^{17}$, the waiting time for tractors may not be rather long. In consequence, farmers are likely to have considerable incentives to use mechanical power as a substitute for time in major irrigation schemes. Empirical evidences in support of this conclusion can be provided. When a number of sample farmers who use mechanical power for ploughing in two major irrigation schemes were asked to rank a given list of reasons for their preference, following results were obtained (Table 11).

Table 11 Reasons for Preferring Tractors in Two Major Irrigation Schemes in Sri Lanka

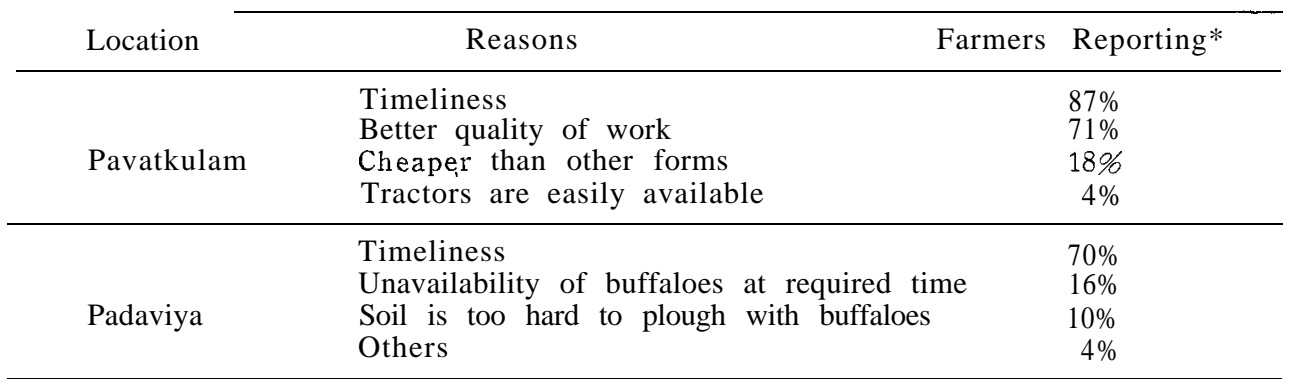

Source: ARTI, A Study of Five Settlement Schemes prior to Irrigation Modernization, Vol. 3 Pavatkulam, Vol. 5 Padaviya

Note: * Multiple responses had been given by some farmers.

Utilization of an excessive volume of water to make soft the soils on paddy fields before the commencement of the ploughing operation, has been a long standing tradition among Sri Lankan farmers. Especially in the dry zone ${ }^{18}$ where the ploughing period is preceeded by a long dry season with hot wind, the soils on paddy fields are very dry and hard. Since all major irrigation schemes are in the dry zone, the farmers there require power units with greater HP, unless soils are softened with an excessive volume of water. If water is not adequately provided, they have to add more number of buffalo pairs per day per unit area than they otherwise do. If not, they would not be able to stand with the strictly time-schedulled cultivation calendar. If a greater number of buffalo pairs were employed, the number of buffalo pairs required per day per unit area may exceed the number of own

16) Farrington, J. and F. Abeyratne 1982

17) Ulluwishewa, R. 1978.

18) Dry zone is the reagion with a rainfall of less than 20 inches for the south-west monsoon (May-September) period (Figure 1). 
buffalo pairs and the capacity of the family labour force. It generates the need for hired labour and hired buffalo. At this point, it is important to understand the cost difference between the usage of a few buffalo pairs for many days and the usage of many buffalo pairs for a few days. In the former case, owned family resources (owned buffaloes and family labour) may be sufficient but in the latter case an additional number of buffalo pairs and labourers have to be hired. Therefore, the second case invariably increases the cash expenditure on power and labour inputs. Even if the extra cash expenditure on hired buffaloes and hired labour is left aside; the rising need for more buffalo pairs and labourers with increasing dryness and hardness of soils, may discourage farmers to depend on buffalo power because it is very difficult for them to assemble quite a large amount of hired buffaloes and labourers during the rather short ploughing period. Therefore, where the soils on paddy fields are very dry and hard at the beginning of the ploughing period, and the sufficient water for pre-softening soils can hardly be made available, farmers are likely to substitute mechanical power for animal power.

In major irrigation schemes, restrictions on the utilization of a greater volume of irrigation water for pre-softening soils were observed to be rather severe. Although the irrigation water is provided free of charge for farmers, the costs incurred in it is extremely high (Table 12). The total cost of water is covered by the state. Therefore, the objective of the state is to maximize the output per unit of irrigation water whereas the objective of farmers is to produce a certain amount of rice at the lowest possible cost. Therefore, the state (in this case the irrigation authority) makes full effort to constrain the excessive utilization of water for pre-softening soils while the farmers make full efforts to utilize much water for pre-softening soils so that the ploughing operation could be performed by small buffalo teams with low cost. The irrigation officials in major irrigation schemes are directly responsible to the state. Therefore, unlike small tank villages, they are quite free to strictly implement the irrigation regulations which were designed with a

Table 12 Expenditure on irrigation

\begin{tabular}{|c|c|c|c|c|}
\hline Year & $\begin{array}{c}\text { Capital } \\
\text { Expenditure }\end{array}$ & $\begin{array}{c}\text { Total } \\
\text { Expenditure }\end{array}$ & $\begin{array}{l}\text { Tatal Govt. } \\
\text { Expenditure }\end{array}$ & $\begin{array}{c}\text { Expenditure On Irrigation } \\
\% \text { Of Total Govt. } \\
\text { Expenditure }\end{array}$ \\
\hline 1973 & 28.042 & 37.540 & 5495 & .69 \\
\hline 1974 & 39.229 & 51.429 & 6386 & .81 \\
\hline 1975 & 46.239 & 60.862 & $\begin{array}{l}7783 \\
9314\end{array}$ & $\begin{array}{l}.78 \\
.63\end{array}$ \\
\hline $\begin{array}{l}1976 \\
1978 \\
1979\end{array}$ & $\begin{array}{l}\mathbf{\$ 3 . 8 8 3} \\
\mathbf{1 4 4 . 3 9 1} \\
313.182^{*}\end{array}$ & $\begin{array}{l}89.788 \\
198.382 \\
402.184^{*}\end{array}$ & $\begin{array}{l}9760 \\
18853 \\
17729 *\end{array}$ & $\begin{array}{l}.87 \\
1.05 \\
2.27\end{array}$ \\
\hline 1980 & $431.554 *$ & $539.031 *$ & $21182^{*}$ & 2.54 \\
\hline
\end{tabular}

Source: Estimates of the Revenue and Expenditure of the government of Sri Lanka, Ministry of Finance and Planning 1979, Colombo.

Note: * Estimated

Unit: Rupees Million 
view to maximize the output per unit of water or in other words to prevent farmers from utilizing irrigation water in wasteful manner. From the irrigation authority's point of view, the utilization of water for pre-softening solis is rather unproductive. Not only the irrigation officials want to control the water issues but also they are really able to do it by virtue of the wellfunctioned physical infrastructure pertaining to water issues and water distribution, and of the greater supervisory capacity of the management staff. Therefore, the pre-decided dead lines for water issues are strictly implemented and the illegal water tappings can easily be detected. Thus, the restrictions over water issues prevent farmers from the utilization of sufficient water for pre-softening soils. In consequence, the dependence on buffalo power for ploughing is heavily discouraged by the greater number of buffaloes and buffalo operators required for ploughing under rather dry conditions, which can hardly be made available during the rather short ploughing period. Probably, owing to the cash costs incurred in hired buffaloes and hired labourers, the total cost of buffalo ploughing would rise to the equal level or probably exceed the tractor hire rates. If not, the cost difference between two alternative methods would become so little that the cost advantage associated with buffalo power could be forgone for the sake of convenience associated with mechanical power.

In the light of these evidences it can be concluded that due to the scarcity of time and water available for ploughing operation, farmers in the major irrigation schemes are likely to substitute mechanical power for animal power, and this conclusion is supported by the observed positive correlation ( $r=$ 0.5565) between the percentage of the paddy extent under major irrigation schemes and the percentage of paddy extent ploughed by mechanical farm power.

\section{CONCLUSION}

This model suggests that any increase in paddy extent under major irrigation schemes and buffalo operators' wage rate during the ploughing period and any decrease in buffalo density will increase the mechanization. At present, the accepted strategy to raise the national paddy production is centered around the expansion of paddy extent under major irrigation. The on-going massive multi-purpose irrigation project, Mahaweli Development Project, which is intended to complete by 1986 will allow irrigation of 351,000 acres of new land. In addition, under the irrigation modernization project, 5 more existing major irrigation schemes are intended to be renovated. The decentralized district-level development plans which are heavily financed by foreign agencies also aim at improving irrigation facilities. All these focus on the dry zone. Therefore, the paddy extent under irrigation will substantially expand in the dry zone, and at the same time the cost incurred in water will rise. According to the model, since the paddy extent under major irrigation seems to be the major driving force to mechanization, the mechanization will further be promoted in the dry zone. In the wet zone, with- 
out being major irrigation schemes, mechanization will remain stagnated. There is no sign of taking appropriate steps to improve the buffalo power numerically or in quality. Instead, disincentives for the maintenance and usage of buffalo power appears to operate in major irrigation schemes in the dry zone whereas in the wet zone, being encouraged by the availability of sufficient water, and the availability of sufficient grasses and shade under coconut trees in homesteads together with the adequacy of labour, buffalo mainten ance will continue. At the moment, there are no grounds to expect any significant change in labour supply in near future in the dry zone as well as in the wet zone. Therefore, any significant improvement in mechanization can hardly be expected in the wet zone. This predicted knowledge concerning the future farm power utilization may be helpful for policy formulation and regional planning.

\section{ACKNOWLEDGEMENTS}

The authors wish to thank Dr. Tsunemasa Kawaguchi, Associate Professor and Dr. Satoshi Kai, Assistant Lecturer of the seminar of econometric analysis in agriculture, Faculty of Agriculture, Kyushu University for their constructive comments on the first draft of this paper. Authors are much indebted to Mr. H. M. Nawarathna Banda, Assistant Lecturer and Mr. Wimalasena Hendawitharane, Graduate student of the Department of Geography, Sri Jayewardenapura University, Sri Lanka for their help in collecting data.

\section{REFERENCES}

ART1 1980 A Study of Five Settlement Schemes Prior to Irrigation Modernization. Vol. IV-Vavunikulam. Agrarian Research and Training Institute, Colombo, Sri Lanka.

Crooks G. R. and H. A. Ranbanda 1981 The Economics of Seasonal Labour Migration in Sri Lanka. Agrarian Research and Training Institute, Colombo, Sri Lanka.

Farrington, J. and F. Abeyratne 1982 Farm Power in Sri Lanka. Department of Agricultural Economics and Management, University of Reading, United Kingdom.

Moore, M. P. 1980 Deficit Paddy Farming in Sri Lanka. Sri Lanka Journal of Agrarian Studies, I(2) : 41-45.

Ulluwishewa, R. and K. Tsuchiya 1983 The Socio-Economic Study of the Draught Animal Power in the Dry Zone of Sri Lanka. A Case Study: Hureegama Village. J. Fac. Agr., Kyushu Univ., 28: 51-70.

Ulluwishewa, R. 1978 The Socio-Economic Implications of the Paddy Land Mechanization in Sri Lanka. M. Sc. dissertation (unpublished), University of London. 